\title{
IN VITRO COMPARISON OF CYCLIC FATIGUE RESISTANCE OF PROTAPER NEXT AND TRUSHAPE 3D CONFORMING FILE NICKEL-TITANIUM ROTARY INSTRUMENTS
}

\section{PROTAPER NEXT VE TRUSHAPE 3D CONFORMİNG FİLE NİKEL-TİTANYUM DÖNER ALETLERİNİN DÖNGÜSEL YORULMA DİRENÇLERİNİN İN VITRO OLARAK KARŞILAŞTIRILMASI}

\author{
Dr. Öğr. Üyesi Ahmet Demirhan UYGUN* \\ Prof. Dr. Mehmet Sinan EVCİ́*
}

\author{
Dr. Öğr. Üyesi Mehmet ÜNAL** \\ Dr. Öğr. Üyesi Halit ALADAĞ ${ }^{* * *}$
}

Makale Kodu/Article code: 4486

Makale Gönderilme tarihi: 06.07.2020

Kabul Tarihi: 26.11.2020

DOI : $10.17567 /$ ataunidfd. 831765
Ahmet Demirhan Uygun: ORCID ID: 0000-0001-5704-183x

Mehmet Ünal: ORCID ID: 0000-0001-9111-6962

Mehmet Sinan Evcil: ORCID ID: 0000-0002-1011-2351

Halit Aladağ: ORCID ID: 0000-0001-6794-3845

\section{ABSTRACT}

Aim: The purpose of this study was to compare the cyclic fatigue resistance of all instruments of the ProTaper Next (PTN) and TRUShape 3D Conforming File (TRS) systems.

Materials and Methods: A total of 120 nickel-titanium rotary instruments were divided into eight groups: PTN X1, PTN X2, PTN X3, PTN X4, TRS 20/.06v, TRS 25/.06v, TRS 30/.06v and TRS 40/.06v. Each group had 15 instruments. All the instruments were tested for cyclic fatigue resistance in stainless steel artificial canals with $5 \mathrm{~mm}$ radius and $60^{\circ}$ angle of curvature. They were rotated until they got fractured, and the test was performed in a saline solution at $35^{\circ} \mathrm{C}( \pm 2)$. The number of cycles to fracture (NCF) was calculated by measuring the time to fracture. The NCF data were analysed statistically using the KruskalWallis $\mathrm{H}$ and post hoc Tamhane $\mathrm{T} 2$ tests for multiple comparisons (a-level $=0.05$ ).

Results: The PTN X1 group had the highest NCF $(P<0.05)$. There was no statistically significant difference between the X2 and TRS 25/.06 groups $(P>0.05)$. However, there was a statistical difference between the other groups of similar sizes (X1TRS 20/.06v) (X3-TRS 30/.06v) (X4-TRS 40/.06v) $(P<0.05)$.

Conclusion: Within the limitations of this study, most of the PTN instruments (X1, X3, and $\mathrm{X} 4)$ have better cyclic fatigue resistance than do TRS instruments (20/.06, 30/.06 and 40/.06) even if they were manufactured with older technology. This result showed that the S-curve design increases the risk of fracture in instruments with large tapers and tip sizes.

Keywords: cyclic fatigue resistance, S-curve design, TRUShape

öz

Amaç: Bu çalışmanın amacı ProTaper Next (PTN) ve TRUShape 3D Conforming File (TRS) sistemlerindeki tüm döner aletlerin döngüsel yorulma dirençlerinin kıyaslanmasıdır.

Gereç ve Yöntem: Toplam 120 nikel-titanyum döner alet 8 gruba bölündü: PTN X1, PTN X2, PTN X3, PTN X4, TRS 20/.06v, TRS 25/.06v, TRS 30/.06v and TRS 40/.06v. Her bir grupta 15 alet vardı. Tüm aletler $5 \mathrm{~mm}$ yarıçaplı ve $60^{\circ}$ eğimli açıya sahip paslanmaz çelik yapay kanallarda döngüsel yorgunluk direnci açısından test edilmiștir. Aletler kırılana kadar döndürüldü ve test $35^{\circ} \mathrm{C}( \pm 2)$ sıcaklıkta serum solüsyonu içinde gerçekleştirildi. Döngüsel Kırılma sayıSı (DKS), kırılma zamanı ölçülerek hesaplandı. DKS verileri Kruskal-Wallis $\mathrm{H}$ testi ve post-hoc Tamhane T2 çoklu karşılaştırma testleri ile istatistiksel olarak analiz edildi (a-level $=0.05$ ).

Bulgular: PTN X1 grubu en yüksek DKS'ye sahipti $(P<0.05)$. PTN X2 and TRS $25 / .06$ grupları arasında istatistiksel açıdan bir fark yoktu $(P>0.05)$. Benzer boyutlara sahip diğer gruplar arasında ise istatistiksel olarak fark vardı (X1-TRS 20/.06v) (X3-TRS 30/.06v) (X4-TRS 40/.06v) $(P<0.05)$.

Sonuç: Bu çalışmanın sınırları dahilinde, PTN döner aletlerinin bir kısmı (X1, X3 ve X4) daha eski bir teknoloji ile üretilmiş olmalarına ragmen, TRS döner aletlerinden $(20 / .06,30 / .06$ ve 40/.06) daha yüksek döngüsel yorulma direncine sahiptir. Bu sonuç, S-eğimli tasarımın özellikle büyük konik ve uç boyutlarına sahip döner aletlerde kırılma riskini arttırdığını göstermiştir.

Anahtar Kelimeler: döngüsel yorulma direnci, S-eğimli tasarım, TRUShape

${ }^{*}$ Department of Endodontics, Faculty of Dentistry, Afyonkarahisar Sağlık Bilimleri University, Afyonkarahisar.

**Department of Pedodontics, Faculty of Dentistry, Afyonkarahisar Sağlık Bilimleri University, Afyonkarahisar.

*** Department of Endodontics, Faculty of Dentistry, Ataturk University, Erzurum.

Kaynakça Bilgisi: Uygun AD, Ünal M, Evcil S, Aladağ H. In vitro comparison of cyclic fatigue resistance of ProTaper next and TRUShape 3d conforming file nickel-titanium rotary instruments. Atatürk Üniv Dis Hek Fak Derg 2021; 31: 385-9.

Citation Information: Uygun AD, Unal M, Evcil S, Aladag H. ProTaper next ve TRUShape 3D conforming file nikel-titanyum döner aletlerinin döngüsel yorulma dirençlerinin in vitro olarak karşıllaştırılması. J Dent Fac Atatürk Uni 2021; 31: 385-9. 


\section{INTRODUCTION}

Nickel-titanium (NiTi) rotary instruments have become indispensable to root canal treatment with superelasticity and shape memory for many years. ${ }^{1}$ They are produced in a variety of design and manufacturing processes, each aiming to improve performance and safety. Nevertheless, the breakage of these instruments by virtue of cyclic fatigue is still a distressing condition in root canal treatment for clinicians. $^{2,3}$ The breakage of NiTi rotary files can be broadly classified into two types: (i) cyclic fatigue and (ii) torsional stress. ${ }^{4} 5$ Many influences-such as alloy, manufacturing technology, cross section, geometric design and speed, torque, and kinematics-have an effect on the cyclic fatigue resistance of NiTi rotary instruments. ${ }^{6-8}$ Nowadays, instruments with diverse geometric designs are produced from the currently used NiTi rotary systems.

The ProTaper Next system (PTN; Dentsply Maillefer, Ballaigues, Switzerland) is made of a unique NiTi alloy called M-wire. M-wire is manufactured through a thermal treatment process. The PTN system has an off-centred, rectangular cross-sectional design which diminishes the screw effect, taper lock, and torque on any given file by minimizing the contact between the file and the dentinal wall. A great deal of research has been conducted on the subject.6, 9-11

The TRUShape 3D Conforming File system (TRS; Dentsply Tulsa Dental Specialties, Tulsa, OK, USA)-an innovative $\mathrm{NiTi}$ rotary system of instruments-has an off-centred, triangular crosssectional and S-curve design along the cutter part of the instrument recently developed by the same manufacturer. The TRS system is produced by a blue $\mathrm{NiTi}$ alloy with proprietary processing. Thanks to the modified cross section with an eccentric centre of mass (off-centred), only two points of the cross section ever touch the dentinal walls at any one time during canal preparation. ${ }^{12,13}$

The TRS system has attracted attention with its different S-curve design in recent years. Many studies have been conducted comparing the cyclic fatigue resistance of the TRS system with NiTi rotary instruments of other manufacturers. ${ }^{14-16}$ However, these studies are related to the size $25 / .06 \mathrm{v}$ instrument of the system, and there is no study in the literature on the remaining instruments of the system. The objective of this study was, therefore, to evaluate and compare the cyclic fatigue resistance of all the
PTN and TRS systems. The null hypothesis of the study was that there is no difference in the cyclic fatigue resistance between PTN and TRS files.

\section{MATERIALS AND METHODS}

Two different commercial NiTi rotary systems of the same brand, 60 PTN and 60 TRS, were divided into eight groups (with 15 instruments each). The TRS system exists as a series of instruments that are denoted as TRS 20/.06v, TRS 25/.06v, TRS 30/.06v, and TRS $40 / .06 \mathrm{v}$. The PTN system consists of instruments numbered as X1 (17/.04), X2(25/.06), X3 (30/.075), and X4 (40/.06). The X5 (50/.06) instrument was not included in this study because we compared instruments with similar dimensions and there was no equivalent for the $\mathrm{X} 5$ instrument in the TRS system. All the instruments were previously examined using an optical stereomicroscope with $20 x$ magnification to test for the signs of a manufacturing defect.

A custom testing device was built to perform cyclic fatigue testing in this study (Figure 1). A 1:16 reduction contra-angle handpiece was mounted so as not to move for standard contact. An artificial stainless steel canal was mounted on a mobile device to allow three-dimensional positioning in the same way as that of other instruments. According to the method of Pruett et al., ${ }^{17}$ cyclic fatigue testing was performed on an artificial stainless steel canal at a $60^{\circ}$ angle and 5 $\mathrm{mm}$ radius of curvature. In this study, the curvature centre was $5 \mathrm{~mm}$ from the tip of the instrument. All the instruments were rotated with a low-torque motor (VDW Silver; VDW, Munich, Germany), and according to the manufacturer's recommendations, the speed and torque settings were $300 \mathrm{rpm}$ and $300 \mathrm{~g} \mathrm{~cm}^{-1}$ for PTN and TRS instruments. A glass block was placed over the artificial stainless steel canal to allow the breakage to be seen and the broken piece to escape. Cyclic fatigue testing was performed in a saline solution at $35^{\circ} \mathrm{C}( \pm 2)$ heated by a device designed for this experiment, and the temperature was controlled by means of a thermostat.

The instruments were rotated until they were broken, and the time to fracture was recorded in seconds with a chronometer. The number of cycles to fracture (NCF) was calculated. One fractured instrument from each group was examined under a scanning electron microscope (LEO $1430 \mathrm{VP}$, Zeiss Oberkochen, Germany) (Figure 2). The NCF data were first subjected to the Levene test for equality of 
variances and then analysed statistically using the Kruskal-Wallis $\mathrm{H}$ and post hoc Tamhane T2 tests for multiple comparisons. SPSS (v.23.0; IBM Corp., Armonk, NY, USA) was used to analyse the data statistically. The level of significance was set at 0.05 .

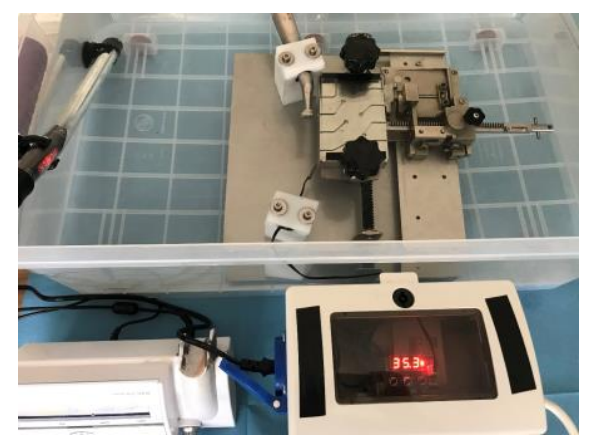

Figure 1. The testing device used for the study.

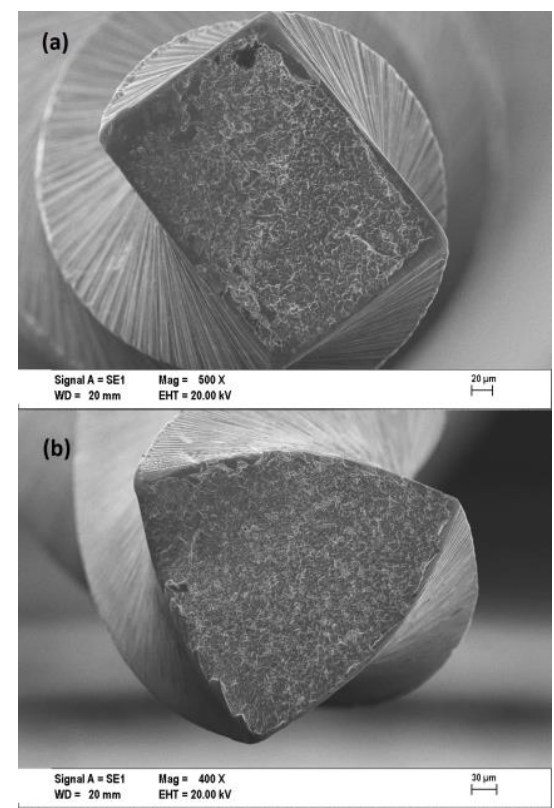

Figure 2. Scanning electron microscope images of ProTaper Next X2 (a) and 25/.06v TRUShape 3D Conforming File (b)

\section{RESULTS}

The mean and standard deviations of NCF for PTN and TRS instruments of different sizes are presented in Table 1. The PTN X1 group had the highest NCF ( $P$ $<0.05)$. There was no statistically significant difference between the $\mathrm{X} 2$ and TRS $25 / .06 \mathrm{v}$ groups ( $P$ $>0.05)$. However, there was a statistical differrrence between the other groups (X1-TRS 20/.06v) (X3-TRS 30/.06v) (X4-TRS 40/.06v) $(P<0.05)$.
Table 1. The Mean and Standard Deviation (SD) Values for the Number of Cycles to Fracture

\begin{tabular}{lll}
\hline & MEAN & SD \\
\hline PTN X1 & $991,66^{\mathrm{a}}$ & 85,78 \\
PTN X2 & $674,66^{\mathrm{c}}$ & 48,34 \\
PTN X3 & $616,66^{\mathrm{d}}$ & 39,80 \\
PTN X4 & $497,66^{\mathrm{e}}$ & 27,50 \\
TRS 20/.06v & $766,33^{\mathrm{b}}$ & 59,53 \\
TRS 25/.06v & $655,33^{\mathrm{cd}}$ & 49,36 \\
TRS 30/.06v & $552,00^{\mathrm{e}}$ & 52,50 \\
TRS 40/.06v & $649,79^{\mathrm{f}}$ & 37,23 \\
\hline Different symbols indicate a statistically significant difference $(P$ & \\
O.05).
\end{tabular}

\section{DISCUSSION}

Generally, a fracture resistance study is performed by selecting the instruments of multipleinstrument systems, with only a certain size. However, making inferences about other elements of the system with only one instrument is not the right approach, especially about the TRS system with a unique design. Therefore, in this study, all the instruments of the PTN and TRS systems were compared with their counterparts with similar dimensions. A file system with S-curve design, such as TRS, is not available to our knowledge. Although it is not exactly the same, there is an instrument called $\mathrm{Xp}$-endo Shaper with an offset design similar to it, but it is only a singleinstrument system and not a multiple-instrument one. Therefore, it is not known how the S-curve design affects cyclic fatigue resistance in instruments with different tapers and tip sizes. Hence, it should be examined especially in such instruments. In this study, it was compared with the PTN system, which is produced by the same manufacturer.

It is important for clinicians to consider positive and negative aspects of PTN and TRS instruments to prefer a more appropriate file system in different cases. The S-curve design of TRS instruments is able to conserve dentine by limited dentine removal and minimal canal transportation. ${ }^{12}$ Another study has shown that TRS instruments are effective in removing calcium hydroxide from artificially created grooves on the canal walls. ${ }^{18}$ Despite these advantages, in the present study, the TRS system has lower cyclic fatigue resistance compared with the PTN system produced before it and with old technology. Thus, the null hypothesis of the present study was rejected.

As a result of our work, most (not all) of the PTN instruments have better cyclic fatigue resistance than the similar-size counterparts of the rotary files of the TRS system, even if it was manufactured with

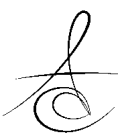


newer technology. Likewise, the S-curve design has been shown to reduce cyclic fatigue resistance compared with straight-designed instruments with larger tapers and tip sizes. In particular, TRS instruments (30/.06v and 40/.06v) with larger tapers and tip sizes have been shown to increase the risk of instrument fracture in curved root canals more. Because X1 (17/.04) has the smallest taper and tipsize instrument, it had the highest cyclic fatigue resistance, as expected in this study. V1 (20/.06v) had larger dimensions than $\mathrm{X} 1$. There was no statistically significant difference between X2 (25/.06) and V2 (25/.06v) instruments $(P>.05)$.

It has been reported in a recent study that PTN X2 instruments had higher cyclic fatigue resistance than TRS 25/.06v instruments had in a stainless steel artificial canal at room temperature. ${ }^{16}$ However, according to developments in recent years, it has been shown that the ambient temperature affects the mechanical properties of $\mathrm{NiTi}$ rotary instruments, and it is more appropriate to perform these studies at intracanal temperature rather than room temperature. ${ }^{14,} 19$ This study was conducted at intracanal temperature, and this result might have occurred because of the difference in experimental set-ups. Instrument fracture due to cyclic fatigue results from the accumulation of compressive and tensile stresses on the curvature area of the root canal. However, in this study and most of the studies in the literature, although the S-curve design of the TRS system distributes the stress instead of collecting it at a point on the curvature area, the design does not have higher cyclic fatigue resistance than do straight-designed files. ${ }^{14}, 16,20$ Nevertheless, Shen et al. ${ }^{[20]}$ evaluated the cyclic fatigue resistance of TRS and other NiTi instruments in a single curvature $\left(60^{\circ}\right)$ and two different double curvatures $\left(60^{\circ}-30^{\circ}\right)\left(60^{\circ}-\right.$ $60^{\circ}$ ). They reported that the fatigue resistance of TRS instruments was higher than that of other instruments only in double-curvature canals. They claimed that this result is due to the TRS instrument moving slightly axially within the canal (especially in double-curvature canals) thanks to the S-curve design, reducing stress concentration in the same area. The resistance to fracture is enhanced. ${ }^{21}$

In this study, most of the PTN instruments were found to have higher fracture resistance compared with TRS instruments. This result can be thought to be due not only to the design of the instruments but also to their alloys. The PTN system is produced by a NiTi alloy called M-wire, a material that undergoes a proprietary thermomechanical process to improve cyclic fatigue resistance compared with classic NiTi alloy. ${ }^{22}$ As far as known, the TRS system is produced by a NiTi alloy with proprietary processing. In a study comparing the thermal phase transitions of these NiTi instruments, PTN instruments displayed a classic austenite-martensite (presumably cubicmonoclinic) phase transformation centred close to body temperature. On the contrary, TRS instruments showed classic R-phase transformations. However, in both the cooling and heating cycles, the R-phase and martensitic transformations overlap and cannot be separated in terms of transformation temperature. That is, there is no difference in fatigue resistance between conventional (non-heat-treated) NiTi alloy and alloy of the TRS system. ${ }^{23}$

\section{CONCLUSION}

Within the limitations of this study, the TRS instruments (30/.06v and 40/.06v) with larger tapers and tip sizes have lower cyclic fatigue resistance than do PTN instruments (X3 and $\mathrm{X} 4$ ). This result showed that the S-curve design increases the risk of instrument fracture in larger tapers and tip sizes. Studies are required in which S-curved instruments are compared with straight-designed $\mathrm{NiTi}$ instruments in terms of their fracture resistance.

\section{Conflicts of interest}

There are no conflicts of interest.

Acknowledgements

The authors declare that there were no other contributors involved in this work

\section{REFERENCES}

1. Walia HM, Brantley WA, Gerstein H. An initial investigation of the bending and torsional properties of Nitinol root canal files. J Endod 1988; 14:346-51.

2. Sattapan B, Nervo GJ, Palamara JE, Messer HH. Defects in rotary nickel-titanium files after clinical use. J Endod 2000; 26:161-5.

3. Rodrigues E, De-Deus G, Souza E, Silva EJ. Safe Mechanical Preparation with Reciprocation Movement without Glide Path Creation: Result from a Pool of 673 Root Canals. Braz Dent J 2016; 27:22-7.

4. Shen Y, Cheung GS-p, Bian Z, Peng B. Comparison of defects in ProFile and ProTaper systems after clinical use. J Endod 2006; 32:61-5. 
5. Cheung GS. Instrument fracture: mechanisms, removal of fragments, and clinical outcomes. Endod Topics 2007; 16:1-26.

6. Uygun AD, Kol E, Topcu M, Seckin F, Ersoy I, Tanriver M. Variations in cyclic fatigue resistance among ProTaper Gold, ProTaper Next and ProTaper Universal instruments at different levels. Int Endod J 2016; 49:494-9.

7. Arslan H, Alsancak M, Doğanay E, Karataş E, Davut Çapar I, Ertas $\mathrm{H}$. Cyclic fatigue analysis of $\mathrm{R}$ eciproc $R \quad 25 \AA$ instruments with different kinematics. Aust Endod J 2016; 42:22-4.

8. Kim H-C, Kwak S-W, Cheung GS-P, Ko D-H, Chung $\mathrm{S}-\mathrm{M}$, Lee W. Cyclic fatigue and torsional resistance of two new nickel-titanium instruments used in reciprocation motion: Reciproc versus WaveOne. J Endod 2012; 38:541-4.

9. Ruddle $\mathrm{CJ}$, Machtou P, West JD. The shaping movement: fifth-generation technology. Dent Today 2013; 32:94, 96-9.

10. Pérez-Higueras $\mathrm{J}$, Arias $A$, José $C$, Peters $O A$. Differences in cyclic fatigue resistance between ProTaper Next and ProTaper Universal instruments at different levels. J Endod 2014; 40:1477-81.

11. Zan R, Hubbezoğlu I, Akpınar KE, Kutlu G, Mutlu Z. Flexural strenght of root dentin after root canal preparation using One-shape new generation, K3XF, Twisted File Adaptive, and ProTaper Next instrumentation systems. J Dent Fac Atatürk Uni 2016; 26:239-44.

12. Peters OA, Arias A, Paqué F. A micro-computed tomographic assessment of root canal preparation with a novel instrument, TRUShape, in mesial roots of mandibular molars. J Endod 2015; 41:1545-50.

13. Bortoluzzi EA, Carlon Jr D, Meghil MM, El-Awady $A R$, Niu L, Bergeron BE, Susin L, Cutler CW, Pashley DH, Tay FR. Efficacy of 3D conforming nickel titanium rotary instruments in eliminating canal wall bacteria from oval-shaped root canals. J Dent 2015; 43:597-604.

14. de Vasconcelos RA, Murphy $S$, Carvalho CAT, Govindjee RG, Govindjee S, Peters OA. Evidence for reduced fatigue resistance of contemporary rotary instruments exposed to body temperature. J Endod 2016; 42:782-7.

15. Kaval ME, Capar ID, Ertas H, Sen BH. Comparative evaluation of cyclic fatigue resistance of four different nickel-titanium rotary files with different cross-sectional designs and alloy properties. Clin Oral Investig 2017; 21:1527-30.
16. Elnaghy A, Elsaka S. Laboratory comparison of the mechanical properties of TRUS hape with several nickel-titanium rotary instruments. Int Endod J 2017; 50:805-12.

17. Pruett JP, Clement DJ, Carnes Jr DL. Cyclic fatigue testing of nickel-titanium endodontic instruments. J Endod 1997; 23:77-85.

18. Uygun AD, Gündoğdu EC, Arslan H, Ersoy I. Efficacy of XP-endo finisher and TRUS hape 3D conforming file compared to conventional and ultrasonic irrigation in removing calcium hydroxide. Aust Endod J 2017; 43:89-93.

19. Plotino G, Grande NM, Bellido MM, Testarelli L, Gambarini G. Influence of temperature on cyclic fatigue resistance of ProTaper Gold and ProTaper Universal rotary files. J Endod 2017; 43:200-2.

20. Elnaghy A, Elsaka S. Cyclic fatigue resistance of XP-endo Shaper compared with different nickeltitanium alloy instruments. Clin Oral Investig 2018; 22:1433-7.

21. Shen $Y$, Hieawy A, Huang X, Wang Z-j, Maezono $H$, Haapasalo M. Fatigue resistance of a 3dimensional conforming nickel-titanium rotary instrument in double curvatures. J Endod 2016; 42:961-4.

22. Ye J, Gao Y. Metallurgical characterization of MWire nickel-titanium shape memory alloy used for endodontic rotary instruments during low-cycle fatigue. J Endod 2012; 38:105-7.

23. Govindjee R, Govindjee S. Thermal phase transformations in commercial dental files. Structural Engineering Mechanics and Materials. Report No. UCB/SEMM-2015/02, 2015. Available at:http://faculty.ce.berkeley.edu/sanjay/ucb_semm _2015_02.pdf. Accessed July 14,2021.

\section{Sorumlu Yazarın Yazışma Adresi}

Ahmet Demirhan UYGUN

Department of Endodontics, Faculty of

Dentistry,

Afyonkarahisar Sağlık Bilimleri University, Afyonkarahisar, 03030, TURKEY

Business telephone number: +90.272 21679

00

Mobile telephone number: +90.505 7513705

Fax number: +90.272 2167080

E-mail address: ademirhan100@hotmail.com 